\title{
Correction to: First record of courtship display of Strix huhula (Strigiformes: Strigidae) in the Brazilian Western Amazon
}

\author{
Marllus Rafael Negreiros de Almeida ${ }^{1,2,3} \cdot$ Jessica Gomes da Costa ${ }^{2} \cdot$ Adriele Karlokoski $^{2,3} \cdot$ Igor Oliveira $^{1,3}$
}

Published online: 9 August 2021

(c) Sociedade Brasileira de Ornitologia 2021

\section{Correction to: Ornithology Research (2021) 29:79-83}

https://doi.org/10.1007/s43388-021-00050-5

This article was updated to delete the reference to Menq (2013) in the Introduction, and in the caption for Figure, 1 text was changed to read: vocalization of presumed female (a).

The original article can be found online at https://doi.org/10.1007/ s43388-021-00050-5.

Marllus Rafael Negreiros de Almeida rafaelbio2011@gmail.com

1 Programa de Pós-Graduação em Ciências Ambientais, Universidade Federal do Acre, Campus Floresta, Estrada da Canela Fina s/n, Cruzeiro do Sul, Acre 69980-000, Brazil

2 Laboratório de Sensoriamento Remoto Aplicado ao Meio Ambiente (LabGAMA), Centro Multidisciplinar, Universidade Federal do Acre, Campus Floresta, Estrada da Canela Fina s/n, Cruzeiro do Sul, Acre 69980-000, Brazil

3 Laboratório de Pesquisas em Etnociências, Ecologia e Conservação (EtnoLab), Centro de Educação e Letras, Universidade Federal do Acre, Campus Floresta, Estrada da Canela Fina s/n, Cruzeiro do Sul, Acre 69980-000, Brazil 